\title{
Stream contamination by trace elements: biota incorporation and phytoremediation
}

\author{
Contaminação de riachos por elementos traço: incorporação pela biota e \\ fitorremediação
}

\section{Rafael Chaves Loureiro ${ }^{1}$ (D) and Luiz Ubiratan Hepp ${ }^{2 *}$ (D)}

\author{
${ }^{1}$ Programa de Pós-graduação em Biologia de Ambientes Aquáticos Continentais, Universidade \\ Federal do Rio Grande, Avenida Itália, Km 8, Campus Carreiros, CEP 96203-900, \\ Rio Grande, RS, Brasil
}

${ }^{2}$ Programa de Pós-graduação em Ecologia, Universidade Regional Integrada do Alto Uruguai e das Missōes - URI, Avenida Sete de Setembro, 1621, CEP 99709-910, Erechim, RS, Brasil

*e-mail: luizuhepp@gmail.com

Cite as: Loureiro, R.C. and Hepp, L.U. Stream contamination by trace elements: biota incorporation and phytoremediation. Acta Limnologica Brasiliensia, 2020, vol. 32, e201.

Abstract: In this review, we present information about the presence of trace elements on streams and the consequences related to the increase of these chemical elements on aquatic systems. Although several studies on trace elements contamination in aquatic environments are conducted on point sources, non-point sources also have a high potential to contaminate water bodies. Some trace elements are important for the development of an organism. However, even essential elements, in high concentrations, may be toxic to aquatic organisms. In some cases, trace elements may accumulate and be transferred along food webs, generating changes in the structure and functioning of terrestrial ecosystems. The phytoremediation techniques could be an important tool in reducing the problems generated by trace elements. Thus, understanding the effects generated by the increase of trace elements concentrations on aquatic ecosystems becomes important to help public managers to apply solutions for the mitigation of this chemical pollution on natural resources.

Keywords: bioaccumulation; biomagnification; heavy metals; metalloids.

Resumo: Nesta revisão apresentamos algumas informaçóes sobre a presença dos elementos traço em riachos e os problemas que o aumento destas concentrações podem causar para estes ambientes. Apesar de grande parte dos estudos sobre contaminação de elementos traço em ambientes aquáticos serem realizados em fontes pontuais de contaminação, as fontes náo-pontuais também tem um elevado potencial para contaminar os corpos hídricos. Alguns elementos traço são importantes para o desenvolvimento dos organismos. No entanto, mesmo elementos essenciais, em altas concentraçóes, podem ser tóxicos para os organismos aquáticos. Em alguns casos os elementos traço podem acumular e ser transferidos ao longo das redes alimentares, gerando alteraçôes na estrutura e funcionamento destes ambientes. As técnicas de fitorremediação podem se tornar importantes ferramentas na redução dos problemas gerados por estes elementos. Assim, compreender os efeitos gerados pelo aumento nas concentraçôes de elementos traço nos ecossistemas aquáticos se torna importante para auxiliar os gestores públicos a buscar soluçôes para a mitigaçáo desta poluição química aos recursos naturais.

Palavras-chave: bioacumulação; biomagnificação; metais pesados; metalóides. 


\section{Introduction}

The agriculture modernization, with the aim of improving productivity, has considerably increased the replacement of native vegetation for cultivated areas and the use of agrochemicals is also growing (Foley et al., 2011). In 2015, in Brazil, approximately 899 million liters of pesticides were used in 71.2 million hectares of crops and soybeans represent the crop with the largest planted area, averaging 17.7 1/ha (Pignati et al., 2017). The removal of native vegetation by agriculture practices is responsible for changes in terrestrial environments (Molina et al., 2017), such as soil erosion, changes in biogeochemical cycles (Lemaire et al., 2014) and soil contamination (Atafar et al., 2010). Fertilizers and pesticides used in crops contain high concentrations of trace elements, such as lead $(\mathrm{Pb})$, nickel $(\mathrm{Ni})$, chromium $(\mathrm{Cr})$, cadmium $(\mathrm{Cd})$, arsenic $(\mathrm{As})$, copper $(\mathrm{Cu})$, zinc $(\mathrm{Zn})$, and others (Nziguheba \& Smolders, 2008; Atafar et al., 2010). Initially, trace elements are responsible for soil contamination of cultivable areas (Yang et al., 2013), and later can easily be carried to water bodies, increasing sediment and water concentrations (Corbi et al., 2008).

Soybeans are the fastest growing crop in the world and Brazil is the second-largest producer in the world (Martins et al., 2018). The use of phosphate fertilizers is one of the main strategies for the best crop yield (Caires et al., 2017). Threfore, the use of phosphate fertilizers in soybean crops has become a source of accumulation of trace elements for agricultural land use. Phosphate rocks used in the formulation of phosphate fertilizers may have trace elements such as $\mathrm{Cu}, \mathrm{Cd}$ and $\mathrm{As}$ (He et al., 2005). In addition, the presence of trace elements in agricultural practices may be associated with the edaphic characteristics (Marrugo-Negrete et al., 2017) and other fertilizers and pesticides used in crops (Kelepertzis, 2014).

The increase in trace element concentrations has been considered a severe problem of environmental pollution in aquatic environments, especially in rivers and streams (Stankovic et al., 2014). These problems focus on their toxicity and capacity of incorporation by the organisms (Rogel et al., 2004; Teng et al., 2015). In view of this problem, strategies for the removal of trace elements from the environment have been used to mitigate effects on the environment (Lee, 2013). Different techniques for remediation have been used in situ to immobilize trace elements in the environment, such as amendments, sand cap and phytoremediation
(Peng et al., 2009). The phytoremediation consists of a natural ability of plants to remove, reduce and/or degrade toxic elements in the environment (Peng et al., 2009). The phytoremediation has been considered a great approach in reducing trace element concentrations (Pratas et al., 2014; Demarco et al., 2018), because of its low cost and it is an ecologically correct approach (Lee, 2013).

In this sense, the increasing knowledge about the effects of agriculture on aquatic environments is essential for decision-makers leading water resources management. In this work, we showed information from studies and researches on trace elements toxicity on aquatic organisms, considering the different incorporation forms into the aquatic trophic chain and eventual transference to the terrestrial environment. In addition, we will present comments about possible approaches for aquatic environments remediation as a way to mitigate these effects and guide public managers. Our focus will be on small streams since about $2 / 3$ of the river basin is drained by them (Allan \& Castillo, 2007). Moreover, we will consider areas of extreme agricultural activity, where the upper river basins become susceptible to this type of impact.

\section{Trace Elements on Aquatic Environments}

Trace elements mean elements present at low concentrations in the ecosystems. The trace elements may be present in aquatic environments in a natural and/or anthropogenic way (Rainbow, 2002). In natural environments, trace element concentrations are controlled by geological factors, such as rock weathering (Magalhães et al., 2015), and generally, do not affect the environment as they are present in low concentrations. On the other hand, in environments impacted by anthropic activities, the main sources of contamination of trace elements are mining, industrialization, urbanization, and agriculture (Xu et al., 2014).

The streams contamination influenced by agricultural activities has been investigated in recent years (Szöcs et al., 2017; Kroflič et al., 2018; Loureiro et al., 2018). The formulation of fertilizers and pesticides is associated with a large variety of trace elements (Atafar et al., 2010). Thus, the concentrations of the compounds responsible for environmental contamination may vary according to soil type, crop and forms of management used (He et al., 2005).

In the aquatic environment, the trace elements distribution is associated with the physical properties and chemical speciation of each element. In general, 
trace elements may be associated with fractions of different sizes, such as the dissolved fraction $(1<\mathrm{kDa})$, colloidal $(1 \mathrm{kDa}-0.45 \mu \mathrm{m})$ and particulate $(>0.45 \mu \mathrm{m})$ (Nystrand et al. 2012). The partition of trace elements under different forms depends mainly on temperature, $\mathrm{pH}$ and redox potential (Aguilar-Hinojosa et al., 2016). The limnic sediment is an important reservoir of trace elements, where changes in the physical and chemical characteristics of water can mobilize and release trace elements to the water column (Montalvo et al., 2014), making them available to the organisms.

The chemical speciation of the trace elements is the conditions in which the elements are in the environment. The trace elements are found in the environment in a variety of forms, including organic and inorganic complexes and hydrated free ions (Slaveykova \& Wilkinson, 2005). The trace element forms derived from the speciation processes determine their availability and toxicity to the aquatic biota. Arsenic, for example, is mainly found on the trivalent (AsIII) and pentavalent forms (AsV), although the two forms are considered toxic, the trivalent form can be more toxic (Singh et al., 2015).

\section{Incorporation And Mobility Of Trace Elements By Aquatic Invertebrates}

When related to aquatic biota, trace elements are classified into two categories. The first group consists of the essential elements (e.g., $\mathrm{Cu}, \mathrm{Zn}$, and $\mathrm{Mn}$ ). These elements play an important role in the metabolism of the organisms (Lebrun et al., 2014). However, they can also produce toxic effects when absorbed and/or adsorbed in excess by organisms (Tüzen, 2009). Zinc, for example, is an essential component for some enzymes (e.g., metalloproteinases, peptidases and carbonic anhydrase). The copper is present mainly in the respiratory protein hemocyanin (Rainbow, 2002). The second group is the non-essential elements (e.g., As, Cd, Pb, Hg, Ni). These elements do not exert a well-defined function for aquatic biota and may be toxic even at low concentrations (Torres et al., 2008). Non-essential elements when accumulated may affect growth and reproduction rates of aquatic organisms (Adams et al., 2011).

Aquatic invertebrates include different taxa of aquatic and semi-aquatic organisms that play an important role in the food chain, transforming organic matter in fine particles and serving as a food resource for other vertebrate organisms. For aquatic invertebrates, exposure to metal may occur from adsorption by their exoskeleton and/or by feed (Magalhães et al., 2015). The incorporation of the trace element by adsorption occurs in direct contact with the environment (e.g., stream water). This incorporation form is common when organisms live in environments with higher concentrations of trace elements, or when they remain for a long time exposed to the element (Hepp et al., 2017). On the other hand, incorporation by food consumption is the most common form, since invertebrates are

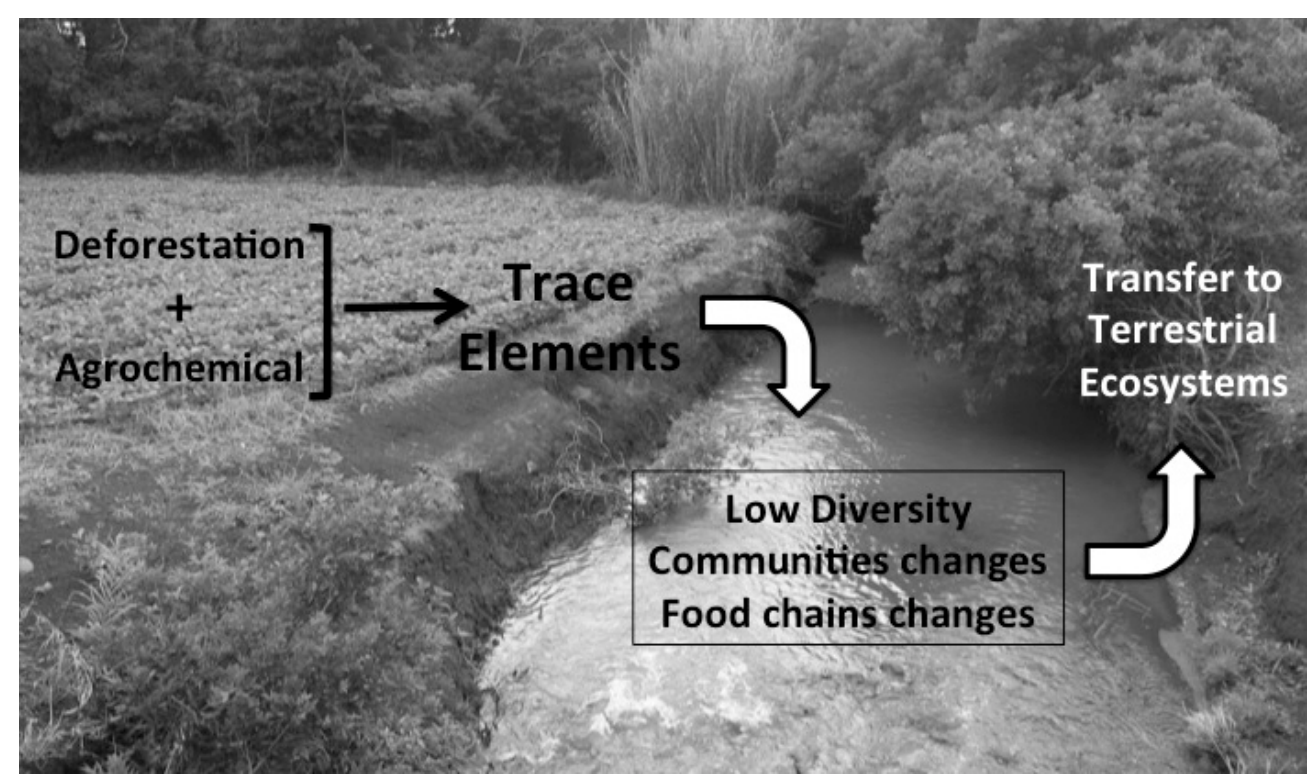

Figure 1. Route of contamination in streams/riparian zone by trace elements from agricultural practices and their transfer to the terrestrial ecosystems. 
effectively in the aquatic food chain (Figure 1; Loureiro et al., 2018).

When incorporated by the organism, the destiny of the trace element is associated with processes of metabolism and/or excretion (Rainbow, 2002). Essential or non-essential trace elements accumulated can be transferred to a biologically inactive compartment and need to be excreted to avoid toxic effects on the organism (Rainbow, 2002). The exoskeleton storage of trace elements may be a strategy for their regulation and later elimination, from the ecdysis process (Keteles \& Fleeger, 2001; Mogren et al., 2012).

The ability to incorporate and excrete trace elements can determine the potential for bioaccumulation of each element in organisms. The bioaccumulation occurs when the rates of incorporation are stored faster than they are metabolized or excreted (Luoma \& Rainbow, 2005). In turn, bioaccumulation may vary according to the organism feed strategy (Rodriguez et al., 2018). For example, trace element concentrations in the biofilm may reflect the anthropization degree of the surrounding streams (Ancion et al., 2013). The biofilm is a significant source of food for primary consumers (e.g., scrapers; Collins et al., 2016), and maybe an important source of trace element incorporation in the trophic chain (Loureiro et al., 2018).

In addition to the ability of trace elements to accumulate in organisms, biomagnification is another important mechanism for incorporating contaminants into the aquatic food chain. While bioaccumulation is associated with the body's ability to accumulate trace elements by absorption/ingestion over time, biomagnification refers to trace element transference to higher levels of the trophic chain. Because trace elements have different chemical characteristics, they show different behaviors when incorporated into the food chain. In general, organisms develop physiological strategies for the elements excretion, so they are hardly biomagnified, as is the case of arsenic, for example (Hepp et al., 2017). On the other hand, there are trace elements that are biomagnified, because the organisms do not have clear excretion strategies (e.g., mercury; Schmitt et al., 2011). In general, bioaccumulation occurs similarly in impacted environments and is independent of the trace element. On the other hand, biomagnification is exclusively dependent on the chemical characteristics of the trace element and is highlighted because it is a real form of human contamination (Mann et al., 2011).

The aquatic invertebrates can be an important source of contamination for terrestrial environments through food routes (Alberts et al., 2013). Food routes link terrestrial and aquatic environments through the movement of the organisms (Schindler $\&$ Smits, 2017). Aquatic invertebrates are important sources of resources for aquatic (e.g., fish) and terrestrial (e.g., birds) vertebrates (Alberts et al., 2013), which can subsidize both terrestrial and aquatic networks (Kraus et al., 2014).

Most of the aquatic insects have an immature phase on the aquatic environment and the adult phase on the terrestrial environment (Jonsson \& Stenroth, 2016). Thus, the emergency process is a common step in the development of numerous insect species. In this way, considering the insects' ability to incorporate trace elements in their immature phases, the emergence of these organisms may be a real source of contamination to the terrestrial environment (Figure 1; Hepp et al., 2017). An example is the larvae of Leptocerus americanus (Banks, 1899) that, when emerged from streams, was able to transfer about $160 \mathrm{mg}$ of lead to the terrestrial environment in a year (Ryan et al., 2019). In addition, emerging insects correspond to the main source of energy for birds, spiders, and raccoons in riparian zones (Kautza \& Sullivan, 2016) which means that they are quickly incorporated into the terrestrial trophic chain.

\section{Phytoremediation Of Streams Trace Elements}

Strategies for the remediation of aquatic environments contaminated by trace elements have been discussed in recent years (Lee, 2013; Favas et al., 2014). The phytoremediation has been considered an ecologically efficient alternative for the reduction of trace elements in the environment (Lee, 2013). In addition, the phytoremediation process consists of the use of organisms with high capacity for compounds accumulation (e.g., fungi, mosses, aquatic macrophytes; see the reviews Peng et al., 2009; Wasi et al., 2013; Akcil et al., 2015). The selected species must be hyperaccumulating and are involved in the absorption, translocation, sequestration, and degradation of trace elements available on the environment (Favas et al., 2014).

The use of phytoremediation in the recovery of aquatic environments can be classified in different approaches, which vary according to how the phytoremediative species incorporates the chemical elements: (1) Phytoextraction consists in the trace elements absorption by the root, being later translocated and accumulated in the aerial parts (Favas et al., 2014). This approach is the best procedure to remove contaminants from 
the water bodies sediment (Singh et al., 2012 ). (2) Rhizofiltration is defined as the ability of plants to absorb and accumulate trace elements in their roots (Singh et al., 2012). This procedure can be used in environments with low trace element concentrations (Lee, 2013). (3) Phytostabilization is the process that decreases the bioavailability and mobility of trace elements in the environment (Singh et al., 2012). Phytostabilization can be used in contaminated soils near streams, where vegetation can reduce erosion and leach contaminants to the groundwater (Lee, 2013). This process does not degrade the trace element, but reduces the compound ability to migrate to soil and water (Lee, 2013). (4) Phytovolatization consists in the ability of certain plants to absorb the trace elements by the root transforming into non-toxic forms and dispersing to the atmosphere from the volatilization (Favas et al., 2014).

The use of phytoremediation plants is a recent approach and the literature lacks information about which species have the best efficiency in trace elements removal (Lee, 2013). However, these approaches have presented some advantages and disadvantages (Table 1), depending on the plants' efficiency to absorb the elements under certain conditions. In an ex-situ study testing the phytofiltration potential of three species of aquatic macrophytes (Callitriche stagnalis Scop., Potamogeton natans L. and P. pectinatus L.), Pratas et al. (2014) found an approximately 85\% of reduction in uranium concentrations in water. Demarco et al. (2018) observed that the aquatic macrophyte Hydrocotyle ranunculoides L.f. presented high potential for bioremediation for several trace elements (mainly iron and aluminum) from the rizofiltration method.

\section{Final Remarks}

Increasing concentrations of trace elements in aquatic environments have been considered a severe environmental problem. Although most studies involving this type of pollution are associated with point sources of pollution, agricultural expansion and economic development is an eminent activity nowadays. However, the pressure that this activity generates on natural resources, especially water bodies, needs to be better understood. In this brief review, we sought to gather information about the main characteristics of trace elements, their effects on aquatic organisms and ways of remediation of these impacts. However, the effectiveness of the application of mitigation and remediation approaches and technologies will only be effective with (1) the formation of a solid conceptual basis regarding the effects that the trace elements can cause to the aquatic fauna and flora and human health; (2) a real interest of the public managers, in the different government spheres, to foment the improvement of these mitigating mechanisms and human resources qualification and, finally; (3) to have a clear dialogue between managers and science researchers, once that these two groups have a fundamental role in the process. On one side, the researchers with the knowledge and, on the other side, the managers with the possibility of action. However, a more participative society can collaborate with the effectiveness of this cooperation, supervising the actions that must be done with responsibility and commitment, for the conservation and recovery of natural resources (Figure 2).

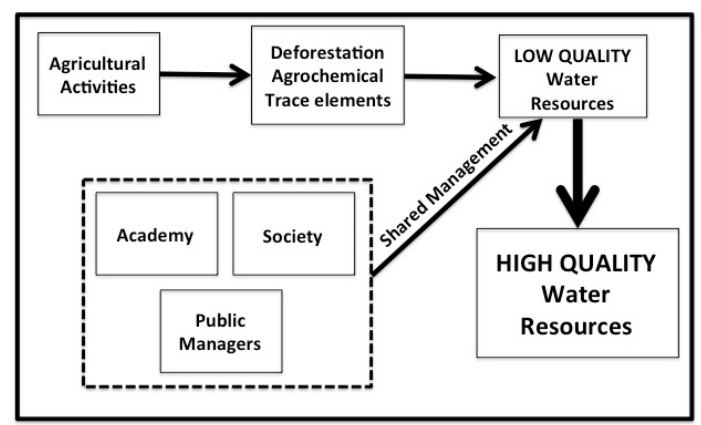

Figure 2. Schematic representation of shared actions among academia, managers and society in favor of improving the quality of water resources.

Table 1. Advantages and disadvantages of using of the phytoremediation approaches to remove trace elements in aquatic environments.

\begin{tabular}{|c|c|}
\hline Advantages & Disadvantages \\
\hline $\begin{array}{l}\text { Low maintenance cost and considered environmentally } \\
\text { friendly }\end{array}$ & $\begin{array}{l}\text { The concentrations of trace elements in the environment } \\
\text { must be within the tolerance limits of the selected species }\end{array}$ \\
\hline Easy acceptance of the general public & Some plants hyperaccumulate only a few trace elements \\
\hline $\begin{array}{l}\text { Contaminated plants are easy to remove from the } \\
\text { environment }\end{array}$ & Biomagnification can occur from the plants used \\
\hline Can be used in situ and ex situ & $\begin{array}{l}\text { Care of the use of non-native species in contaminated } \\
\text { environments }\end{array}$ \\
\hline
\end{tabular}

Adapted from Lee (2013), Favas et al. (2014) and Singh et al. (2012). 


\section{Acknowledgements}

The authors thank Dr. Cristiane Biasi and Dr. Silvia Vendrusculo Milesi for the suggestions about the text and English review. This study was funded in part by the Coordination of Improvement of Higher Education Personnel - Brazil (CAPES) - Finance Code 001. LUH receives financial support from CNPq (process No. 421632/2016-0) and productivity grant $\mathrm{CNPq}$ (process no. 305203/2017-7).

\section{References}

AKCIL, A., ERUST, C., OZDEMIROGLU, S., FONTI, V. and BEOLCHINI, F. A review of approaches and techniques used in aquatic contaminated sediments: Metal removal and stabilization by chemical and biotechnological processes. Journal of Cleaner Production, 2015, 86, 24-36. http://dx.doi. org/10.1016/j.jclepro.2014.08.009.

ADAMS, W.J., BLUST, R., BORGMANN, U., BRIX, K.V., DEFOREST, D.K., GREEN, A.S., MEYER, J.S., MCGEER, J.C., PAQUIN, P.R., RAINBOW, P.S. and WOOD, C.M. Utility of tissue residues for predicting effects of metals on aquatic organisms. Integrated Environmental Assessment and Management, 2011, 7(1), 75-98. http://dx.doi.org/10.1002/ ieam.108. PMid:21184570.

ALLAN, J.D. and CASTILLO, M.M. Stream ecology: structure and function of running waters. $2 \mathrm{nd}$ ed. Dordrecht: Springer Science \& Business Media, 2007, 436 p. http://dx.doi.org/10.1007/978-14020-5583-6.

ALBERTS, J.M., SULLIVAN, S.M. and KAUTZA, A. Riparian swallows as integrators of landscape change in a multiuse river system: Implications for aquaticto-terrestrial transfers of contaminants. The Science of the Total Environment, 2013, 463-464, 42-50. http://dx.doi.org/10.1016/j.scitotenv.2013.05.065. PMid:23792246.

AGUILAR-HINOJOSA, Y., MEZA-FIGUEROA, D., VILLALBA-ATONDO, A.I., ENCINASROMERO, M.A., VALENZUELA-GARCÍA, J.L. and GÓMEZ-ÁLVAREZ, A. Mobility and bioavailability of metals in stream sediments impacted by mining activities: the Jaralito and the Mexicana in Sonora, Mexico. Water, Air, and Soil Pollution, 2016, 227(9), 227-345. http://dx.doi. org/10.1007/s11270-016-3046-1.

ANCION, P.Y., LEAR, G., DOPHEIDE, A. and LEWIS, G.D. Metal concentrations in stream biofilm and sediments and their potential to explain biofilm microbial community structure. Environmental Pollution, 2013, 173, 117-124. http://dx.doi.org/10.1016/j.envpol.2012.10.012. PMid:23202641.
ATAFAR, Z., MESDAGHINIA, A., NOURI, J., HOMAEE, M., YUNESIAN, M., AHMADIMOGHADDAM, M. and MAHVI, A.H. Effect of fertilizer application on soil heavy metal concentration. Environmental Monitoring and Assessment, 2010, 160(1-4), 83-89. http://dx.doi. org/10.1007/s10661-008-0659-x. PMid:19058018.

CAIRES, E.F., SHARR, D.A., JORIS, H.A.W., HALISKI, A. and BINI, A.R. Phosphate fertilization strategies for soybean production after conversion of a degraded pastureland to a no-till cropping system. Geoderma, 2017, 308, 120-129. http://dx.doi. org/10.1016/j.geoderma.2017.08.032.

COLlinS, S.M., KOHLER, T.J., THOMAS, S.A., FETZER, W.W. and FLECKER, A.S. The importance of terrestrial subsidies in stream food webs varies along a stream size gradient. Oikos, 2016, 125(5), 674-685.

CORBI, J.J., TRIVINHO-STRIXINO, S. and SANTOS, A. Environmental evaluation of metals in sediments and dragonflies due to sugar cane cultivation in neotropical streams. Water, Air, and Soil Pollution, 2008, 195(1-4), 325-333. http://dx.doi. org/10.1007/s11270-008-9749-1.

DEMARCO, C.F., AFONSO, T.F., PIENIZ, S., QUADRO, M.S., CAMARGO, F.A.O. and ANDREAZZA, R. In situ phytoremediation characterization of heavy metals promoted by Hydrocotyle ranunculoides at Santa Bárbara stream, an anthropogenic polluted site in southern of Brazil. Environmental Science and Pollution Research International, 2018, 25(28), 28312-28321. http://dx.doi.org/10.1007/s11356-018-2836-y. PMid:30083896.

FAVAS, P.J.C., PRATAS, J., VARUN, M., D'SOUZA, R. and PAUL, M.S. Phytoremediation of soils contaminated with metals and metalloids at mining areas: potential of native flora. In: C.H. SORIANO, ed. Environmental risk assessment of soil contamination. New York: InTech, 2014, pp. 485-517.

FOLEY, J.A., RAMANKUTTY, N., BRAUMAN, K.A., CASSIDY, E.S., GERBER, J.S., JOHNSTON, M., MUELLER, N.D., O'CONNELL, C., RAY, D.K., WEST, P.C., BALZER, C., BENNETT, E.M., CARPENTER, S.R., HILL, J., MONFREDA, C., POLASKY, S., ROCKSTRÖM, J., SHEEHAN, J., SIEBERT, S., TILMAN, D. and ZAKS, D.P.M. Solutions for a cultivated planet. Nature, 2011, 478(7369), 337-342. http://dx.doi.org/10.1038/ nature10452. PMid:21993620.

HE, Z.L., YANG, X.E. and STOFFELLA, P.J. Trace elements in agroecosystems and impacts on the environment. Journal of Trace Elements in Medicine and Biology, 2005, 19(2-3), 125-140. http://dx.doi. org/10.1016/j.jtemb.2005.02.010. PMid:16325528.

HEPP, L.U., PRATAS, J.A. and GRAÇA, M.A.S. Arsenic in stream waters is bioaccumulated but neither 
biomagnified through food webs nor biodispersed to land. Ecotoxicology and Environmental Safety, 2017, 139, 132-138. http://dx.doi.org/10.1016/j. ecoenv.2017.01.035. PMid:28129598.

JONSSON, M. and STENROTH, K. True autochthony and allochthony in aquatic-terrestrial resource fluxes along a landuse gradient. Freshwater Science, 2016, 34(3), 882-894. http://dx.doi.org/10.1086/687840.

KAUTZA, A. and SULLIVAN, S.M.P. The energetic contributions of aquatic primary producers to terrestrial food webs in a mid-size river system. Ecology, 2016, 97(3), 694-705. PMid:27197396.

KELEPERTZIS, E. Accumulation of heavy metals in agricultural soils of Mediterranean: Insights from Argolida basin, Peloponnese, Greece. Geoderma, 2014, 221-222, 82-90. http://dx.doi.org/10.1016/j. geoderma.2014.01.007.

KETELES, K.A. and FLEEGER, J.W. The contribution of ecdysis to the fate of copper, zinc and cadmium in grass shrimp, Palaemonetespugio Holthius. Marine Pollution Bulletin, 2001, 42(12), 1397-1402. http:// dx.doi.org/10.1016/S0025-326X(01)00172-2. PMid:11827128.

KRAUS, J.M., WALTERS, D.M., WESNER, J.S., STRICKER, C.A., SCHMIDT, T.S. and ZUELLIG, R.E. Metamorphosis alters contaminants and chemical tracers in insects: Implications for food webs. Environmental Science \& Technology, 2014, 48(18), 10957-10965. http://dx.doi.org/10.1021/ es502970b. PMid:25136925.

KROFLIČ, A., GERM, M., GOLOB, A. and STIBILJ, V. Does extensive agriculture influence the concentration of trace elements in the aquatic plant Veronica anagallis-aquatica? Ecotoxicology and Environmental Safety, 2018, 150, 123-128. http://dx.doi.org/10.1016/j.ecoenv.2017.10.055. PMid:29272716.

LEBRUN, J.D., UHER, E., TUSSEAU-VUILLEMIN, M.H. and GOURLAY-FRANCÉ, C. Essential metal contents in indigenous gammarids related to exposure levels at the river basin scale: Metal-dependent models of bioaccumulation and geochemical correlations. The Science of the Total Environment, 2014, 466467, 100-108. http://dx.doi.org/10.1016/j. scitotenv.2013.07.003. PMid:23895780.

LEE, J.H. An overview of phytoremediation as a potentially promising technology for environmental pollution control. Biotechnology and Bioprocess Engineering; BBE, 2013, 18(3), 431-439. http:// dx.doi.org/10.1007/s12257-013-0193-8.

LEMAIRE, G., FRANZLUEBBERS, A., CARVALHO, P.C.F. and DEDIEU, B. Integrated crop-livestock systems: Strategies to achieve synergy between agricultural production and environmental quality. Agriculture, Ecosystems \& Environment, 2014, 190, 4-8. http://dx.doi.org/10.1016/j.agee.2013.08.009.
LOUREIRO, R.C., MENEGAT, M.N., RESTELLO, R. and HEPP, L.U. Incorporation of zinc and copper by insects of different functional feeding groups in agricultural streams. Environmental Science and Pollution Research International, 2018, 25(18), 17402-17408. http://dx.doi.org/10.1007/s11356018-1971-9. PMid:29654465.

LUOMA, S.N. and RAINBOW, P.S. Why Is Metal bioaccumulation so variable? Biodynamics as a unifying concept. Environmental Science \& Technology, 2005, 39(7), 1921-1931. http://dx.doi. org/10.1021/es048947e. PMid:15871220.

MAGALHÃES, D.P., MARQUES, M.R.C., BAPTISTA, D.F. and BUSS, D.F. Metal bioavailability and toxicity in freshwaters. Environmental Chemistry Letters, 2015, 13(1), 69-87. http://dx.doi.org/10.1007/s10311015-0491-9.

MANN, R.M., VIJVER, M.G. and PEIJNENBURG, W.J.G.M. Metals and metalloids in terrestrial systems: bioaccumulation, biomagnification and subsequent adverse effects. In: F., SANCHEZBAYO, P.J. VAN DEN BRINK, R.M., MANN, eds. Ecological impacts of toxic chemicals. Sharjah: Bentham Science Publishers, 2011, pp. 43-62.

MARRUGO-NEGRETE, J., PINEDO-HERNÁNDEZ, J. and DÍEZ, S. Assessment of heavy metal pollution, spatial distribution and origin in agricultural soils along the Sinú River Basin, Colombia. Environmental Research, 2017, 154, 380-388. http://dx.doi. org/10.1016/j.envres.2017.01.021. PMid:28189028.

MARTINS, J.A.S., ALVES, A.B., GARCEZ, M. and JULIATTI, F.C. Partial resistance of soybean lines to asian rust and white mold. Bioscience Journal, 2018, 34, 1281-1286. http://dx.doi.org/10.14393/ BJ-v34n5a2018-41867.

MOGREN, C.L., VON KIPARSKI, G.R., PARKER, D.R. and TRUMBLE, J.T. Survival, reproduction, and arsenic body burdens in Chironomus riparius exposed to arsenate and phosphate. The Science of the Total Environment, 2012, 425, 60-65. http://dx.doi.org/10.1016/j.scitotenv.2012.03.009. PMid:22464028.

MOLINA, M.C., ROA-FUENTES, C.A., ZENI, J.O. and CASATTI, L. The effects of land use at different spatial scales on instream features in agricultural streams. Limnologica, 2017, 65, 14-21. http://dx.doi. org/10.1016/j.limno.2017.06.001.

MONTALVO, C., AGUILAR, C.A., AMADOR, L.E., CERON, J.G., CERON, R.M., ANGUEBES, F. and CORDOVA, A.V. Metal Contents in Sediments $(\mathrm{Cd}$, $\mathrm{Cu}, \mathrm{Mg}, \mathrm{Fe}, \mathrm{Mn}$ ) as Indicators of Pollution of Palizada River, Mexico. Environment and Pollution, 2014, 3(4), 89-98. http://dx.doi.org/10.5539/ep.v3n4p89.

NYSTRAND, M.I., OSTERHOLM, P., NYBERG, M.E. and GUSTAFSSON, J.P. Metal speciation in rivers affected by enhanced soil erosion and acidity. 
Applied Geochemistry, 2012, 27(4), 906-916. http:// dx.doi.org/10.1016/j.apgeochem.2012.01.009.

NZIGUHEBA, G. and SMOLDERS, E. Inputs of trace elements in agricultural soils via phosphate fertilizers in European countries. The Science of the Total Environment, 2008, 390(1), 53-57. http://dx.doi.org/10.1016/j.scitotenv.2007.09.031. PMid: 18028985 .

PENG, J., SONG, Y., YUAN, P., CUI, X. and QIU, $\mathrm{G}$. The remediation of heavy metals contaminated sediment. Journal of Hazardous Materials, 2009, 161(2-3), 633-640. http://dx.doi.org/10.1016/j. jhazmat.2008.04.061. PMid:18547718.

PIGNATI, A.W., LIMA, F.A.N.S., LARA, S.S., CORREA, M.L.M., BARBOSA, J.R., LEÃO, L.H.C. and PIGNATTI, M.G. Spatial distribution of pesticide use in Brazil: a strategy for health surveillance. Ciencia \& Saude Coletiva, 2017, 22(10), 3281-3293.

PRATAS, J., PAULO, C., FAVAS, P.J.C. and VENKATACHALAM, P. Potential of aquatic plants for phytofiltration of uranium-contaminated waters in laboratory conditions. Ecological Engineering, 2014, 69, 170-176. http://dx.doi.org/10.1016/j. ecoleng.2014.03.046.

RAINBOW, P. Trace metal concentrations in aquatic invertebrates: why and so what? Environmental Pollution, 2002, 120(3), 497-507. http:// dx.doi.org/10.1016/S0269-7491(02)00238-5. PMid:12442773.

RODRIGUEZ, P., MÉNDEZ-FERNÁNDEZ, L., PARDO, I., COSTAS, N. and MARTINEZMADRID, M. Baseline tissue levels of trace metals and metalloids to approach ecological threshold concentrations in aquatic macroinvertebrates. Ecological Indicators, 2018, 91, 395-409. http:// dx.doi.org/10.1016/j.ecolind.2018.04.004.

ROGEL, J.A., APARICIO, M.J.R., INIESTA, M.J.D. and LOZANO, R.A. Metals and soils and aboveground biomass of plants from a salt marsh polluted by mine wastes in the coast of Mar Menor Lagoon, SE Spain. Fresenius Environmental Bulletin, 2004, 13(3b), 274-278.

RYAN, S.C., BELBY, C.S., KING-HEIDEN, T.C., HARO, R.J., OGOREK, J. and GERRISH, G.A. The role of macroinvertebrates in the distribution of lead $(\mathrm{Pb})$ within an urban marsh ecosystem. Hydrobiologia, 2019, 827(1), 337-352. http://dx.doi. org/10.1007/s10750-018-3785-7.

SCHINDLER, D.E. and SMITS, A.P. Subsidies of Aquatic Resources in Terrestrial Ecosystems. Ecosystems , 2017, 20(1), 78-93. http://dx.doi. org/10.1007/s10021-016-0050-7.

SCHMITT, C.J., STRICKER, C. and BRUMBAUGH, W.G. A and BRUMBAUGH, W.G. Mercury bioaccumulation and biomagnification in
Ozark stream ecosystems. Ecotoxicology and Environmental Safety, 2011, 74(8), 2215-2224. http://dx.doi.org/10.1016/j.ecoenv.2011.08.008. PMid:21868094.

SINGH, D., GUPTA, R. and TIWARI, A. Phytoremediation of lead from wastewater using aquatic plants. International Journal of Biomedical Research. Agricultural Technology (Thailand), 2012, 8(1), 1-11.

SINGH, R., SINGH, S., PARIHAR, P., SINGH, V. and PRASAD, S.M. P and PRASAD, S.M. Arsenic contamination, consequences and remediation techniques: A review. Ecotoxicology and Environmental Safety, 2015, 112, 247-270. http://dx.doi.org/10.1016/j.ecoenv.2014.10.009. PMid:25463877.

SLAVEYKOVA, V.I. and WILKINSON, K.J. Predicting the bioavailability of metals and metal complexes: Critical review of the biotic ligand model. Environmental Chemistry, 2005, 2(1), 9-24. http:// dx.doi.org/10.1071/EN04076.

STANKOVIC, S., KALABA, P. and STANKOVIC, A.R. Biota as toxic metal indicators. Environmental Chemistry Letters, 2014, 12(1), 63-84. http://dx.doi. org/10.1007/s10311-013-0430-6.

SZÖCS, E., BRINKE, M., KARAOGLAN, B. and SCHÄFER, R.B. Large scale risks from agricultural pesticides in small streams. Environmental Science \& Technology, 2017, 51(13), 7378-7385. http://dx.doi. org/10.1021/acs.est.7b00933. PMid:28594168.

TENG, Y., FENG, D., WU, J., ZUO, R., SONG, L. and WANG, J. Distribution, bioavailability, and potential ecological risk of $\mathrm{Cu}, \mathrm{Pb}$, and $\mathrm{Zn}$ in soil in a potential groundwater source area. Environmental Monitoring and Assessment, 2015, 187(5), 187-293. http://dx.doi. org/10.1007/s10661-015-4541-3. PMid:25910722.

TORRES, M.A., BARROS, M.P., CAMPOS, S.C.G., PINTO, E., RAJAMANI, S., SAYRE, R.T. and COLEPICOLO, P. Biochemical biomarkers in algae and marine pollution: A review. Ecotoxicology and Environmental Safety, 2008, 71(1), 1-15. http://dx.doi.org/10.1016/j.ecoenv.2008.05.009. PMid:18599121.

TÜZEN, M. Toxic and essential trace elemental contents in fish species from the Black Sea, Turkey. Food and Chemical Toxicology, 2009, 47(8), 1785-1790. http://dx.doi.org/10.1016/j.fct.2009.04.029. PMid:19406195.

XU, X., ZHAO, Y., ZHAO, X., WANG, Y. and DENG, W. Sources of heavy metal pollution in agricultural soils of a rapidly industrializing area in the Yangtze Delta of China. Ecotoxicology and Environmental Safety, 2014, 108, 161-167. http://dx.doi.org/10.1016/j.ecoenv.2014.07.001. PMid:25063882. 
WASI, S., TABREZ, S. and AHMAD, M. Use of Pseudomonas spp. for the bioremediation of environmental pollutants : a review. Environmental Monitoring and Assessment, 2013, 185(10), 81478155. http://dx.doi.org/10.1007/s10661-0133163-x. PMid:23519843.

YANG, S., ZHOU, D., YU, H., WEI, R. and PAN, B. Distribution and speciation of metals $(\mathrm{Cu}, \mathrm{Zn}$, $\mathrm{Cd}$, and $\mathrm{Pb}$ ) in agricultural and non-agricultural soils near a stream upriver from the Pearl River,
China. Environmental Pollution, 2013, 177, 64-70. http://dx.doi.org/10.1016/j.envpol.2013.01.044. PMid:23466733.

Received: 27 February 2019 Accepted: 20 February 2020

Associate Editors: Rafael Marques Almeida, André Megali Amado, Simone Jaqueline Cardoso, Joyce Andreia dos Santos. 